\title{
Early Childhood Teacher Preparation: Using the Co-Teaching Model
}

\author{
Barbara F. Hartigan \\ School of Education, University of Saint Joseph, West Hartford, USA \\ Email: bhartigan@usj.edu
}

Received 25 March 2014; revised 25 April 2014; accepted 2 May 2014

Copyright (C) 2014 by author and Scientific Research Publishing Inc.

This work is licensed under the Creative Commons Attribution International License (CC BY). http://creativecommons.org/licenses/by/4.0/

(c) (i) Open Access

\begin{abstract}
Previous research shows that co-teaching during the student teaching practicum should be the model used by colleges and universities. This researcher used an open-ended questionnaire, a Likert-type scale survey, and individual conferences to ascertain teacher candidates', cooperating teachers', and university supervisors' perceptions of the co-teaching model's benefits, or lack thereof. The twenty-nine student teachers surveyed represent a private university and earned degrees in early childhood special education. The teacher candidates, cooperating teachers, and university supervisors are hired by the university and are experts in the aforementioned field of education. Findings reveal that pre-teacher candidates, university supervisors, and cooperating teachers all believe that mentoring during student teaching using the co-teaching model is beneficial for both the pre-teacher candidates and students in the classroom if proper professional development is offered and continuous and ongoing reflection and planning take place.
\end{abstract}

\section{Keywords}

Early Childhood Special Education, Teacher Preparation, Co-Teaching, Coaching, Mentoring, Student Teaching

\section{Introduction}

Student teaching is a way to link the theory learned during teacher preparation programs with the real-world application needed for teacher success in the classroom. The traditional model used in most teacher preparation programs has not changed since the 1920s (Guyton \& McIntyre, 1990). This traditional model asks that teacher candidates duplicate the instructional behaviors of a master teacher. After many weeks, and/or months, of observation, support, and practice, the student teacher is allowed to teach on her/his own for a brief period of time. The master teacher is responsible for modeling classroom management, instructional strategies, and daily rou- 
tines, while the student teacher mimics the master teacher's techniques. Using this traditional model, a successful student teaching experience is achieved if the student teacher replicates the master teacher's teaching and classroom management styles. Additionally, in the traditional model of student teaching, little training is completed addressing the personality styles and value systems of the master teacher and teaching candidate. If personality styles clash, changes are usually made in the student-teaching placement.

In contrast, co-teaching allows two adults to work collaboratively to best meet the needs of all learners (Cook \& Friend, 1995). The St. Cloud Teacher Quality Enhancement initiative defines co-teaching as "two teachers (a mentor teacher and a teacher candidate) working together with groups of students; sharing the planning, organization, delivery, and assessment of instruction, as well as the physical space” (Bacharach, Heck, \& Dahlberg, 2010: pp. 4,5) from the start of the student-teaching experience. The mentor teacher is encouraged to make instructional decisions explicit, allowing the invisible workings of the classroom visible to the teacher candidate. As the experience continues, the pair seamlessly alternates between assisting and/or leading the planning, teaching, and evaluation. Co-teaching enhances the learning opportunities for students, combines the knowledge and strengths of both teachers, while modeling positive adult working relationships (Cook \& Friend, 1995). The benefits of co-teaching include "opportunities to vary content presentation, individualize instruction, scaffold learning experiences, and monitor students’ understanding” (Graziano \& Navarrete, 2012: p. 109).

St. Cloud State University's (SCSU) co-teaching model is a research driven model (Bacharach, Heck, \& Dahlberg, 2007) that better prepares student teachers while improving learning for students in the classroom. Ten years of research using a five million dollar grant allowed SCSU to prove that this model statically improves math and reading scores for student learning in a co-taught classroom (York-Barr, Bacharach, Salk Frank, \& Beniek, 2004). Statistics from the study also support that this co-teaching model of student teaching should influence the model of student teaching colleges and universities employ (Bacharach, Heck, \& Dahlberg, 2007).

With the reduced teacher/pupil ratio that co-teaching allows, options for flexible grouping arise and are encouraged (Bawens \& Hourcade, 1995). The co-teaching model supports seven different student grouping approaches: alternative teaching; one teach/one assist; teaming; parallel teaching; station teaching; and one teach/ one observe (Bacharach et al., 2010). Table 1 presents descriptions of each type of co-teaching strategy. All co-teaching approaches support Tier II instruction for students needing alternative learning strategies as outlined in the Response to Intervention model of classroom intervention (Hale, 2008: p. 3).

Table 1. Co-teaching strategies (Bacharach, Heck, \& Dahlberg, 2010).

Type of co-teaching Application

One teacher has primary instructional responsibility while the other gathers specific observational information on students or the (instructing) teacher. The key to this strategy is to focus the

One teach, one observe observation-where the teacher doing the observation is observing specific behaviors. It is important to remember that either (teacher candidate or cooperating teacher) could take on both roles.

One teach, one assist

This is an extension of one teach, one observe. One teacher has primary instructional responsibility while the other assists students' with their work, monitors behaviors, or corrects assignments. Often lending a voice to students or groups who would hesitate to participate or add comments.

Station teaching

The co-teaching pair divides the instructional content into parts. Each teacher instructs one of the groups, groups then rotate or spend a designated amount of time at each station. Often an independent station will be used along with the teacher led station.

Parallel teaching

Each teacher instructs half the students. The two teachers are addressing the same instructional material and presenting the material using the same teaching strategies. The benefit to this approach is the reduction of student to teacher ratio.

Supplemental

This strategy allows one teacher to work with students at their expected grade level, while the other teacher works with those students who need the information and/or materials extended or remediated.

Alternative

(differentiated)

Alternative teaching strategies provide two different approaches to teaching the same information.

The learning outcome is the same for all students; however, the avenue for getting there is different.

Well planned, team taught lesson, exhibit an invisible flow of instruction with no prescribed division

Team teaching of authority. Using a team teaching strategy, both teachers are actively involved in the lesson. From a students' perspective, there is no clearly defined leader-as both teachers share the instruction, are free to interject information, and available to assist students and answer questions. 


\section{Literature Review}

Both literature on mentoring and the St. Cloud State University's co-teaching training model provide the conceptual framework for this study. The training used for cooperating teachers, university supervisors, and teacher candidates was developed as part of the St. Cloud's Teacher Quality Enhancement initiative (Bacharach, Heck, \& Dahlberg, 2010). This training program is very specific and emphasizes preparation for co-teaching for the teacher candidate, cooperating teacher and university supervisor that is centered on teacher collaboration. A full-day workshop devoted to learning about each other's learning style, value preferences, and conflict resolution is suggested by SCSU.

The involvement of the mentor teacher and teacher candidate is drastically different when using co-teaching rather than the traditional model of student teaching. Sandholtz (2011) found four emergent categories in her research of 290 preservice teachers' conceptions of effective and ineffective practices. They are: effective instruction; ineffective instruction; effective classroom management; and ineffective classroom management (p. 32). In a co-teaching student-teaching experience, both instruction and classroom management are shared responsibilities by the cooperating teacher and teacher candidate (Bacharach, Heck, \& Dahlberg, 2010). Keefe, Moore, \& Duff (2004) discuss understanding the co-teacher's teaching methodology and using the strengths of both educators during classroom instruction and planning.

Relationship building begins between the triad (cooperating teacher, university supervisor, and teacher candidate) during the training sessions and continues throughout the student-teaching experience. A foundation of trust and respect is established during the workshop by way of conversations and group activities. Communication and collaboration, according the Friend \& Cook’s Characteristics of Collaboration model (2003) are practiced during the initial training session. Strategies are suggested so that communication and problem-solving continues throughout the student-teaching experience.

Time for planning is essential for co-teaching and was cited by the participants in this study as an essential component to a successful co-teaching environment. Friend \& Cook (2003) highlight the importance of planning time and collaboration and contributions by all parties. In the traditional student teaching setting, the teacher candidate spends time preparing lessons or units of study on their own with little teacher direction or advice. The co-teaching model stresses sharing of ideas and the use of each teacher's strengths to engage all students in the classroom.

Finally, during the training sessions the power difference between the student teacher and cooperating teacher is addressed. The two are urged to work as a team; the teacher candidates are valued and urged to contribute while the cooperating teachers are given mentoring strategies to help the teacher candidate excel in all aspects of the classroom.

\section{Method}

Data sources from three semesters of student teaching were collected for this research which included interviews and open-ended questionnaires, which including a Likert-type scale, from teaching candidates, cooperating teachers, and university supervisors regarding their perceptions of benefits, or lack thereof, of co-teaching for both student teachers and students during co-teaching placements. Interviews were conducted individually with all student teachers, cooperating teachers, and university supervisors before and after the co-teaching student teaching experience to obtain all parties' pre and post perceptions of the student teaching experience. Openended questionnaires were also completed by the triad so that participants could anonymously submit their perceptions of the co-teaching experience.

Forty-nine pre-service candidates were presented information on the co-teaching model of student teaching as part of their pre-student teaching seminars. Additionally, twenty-five college supervisors were trained to supervise using the co-teaching model. Cooperating teachers were trained and invited to use the co-teaching model if they were interested in participating in this research. Twenty cooperating teachers representing, special education and early childhood education, and their student teachers volunteered from urban, suburban and rural settings. The student teaching candidates consisted of twenty-eight females and one male and included a range of ethnic backgrounds: 75\% Caucasian; 8\% Latino; and 17\% African American. District administrators approved the cooperating teachers' involvement. Mentor teachers, university supervisors, and teacher candidate were trained together at their perspective schools. During each semester, the researcher visited each classroom involved to observe the co-teaching model in progress. The researcher was also available to problem-solve specif- 
ic issues during the entirety of each teacher candidate’s placement.

\section{Results}

At the beginning and end of each student teaching placement, teacher candidate (TC-n29), cooperating teacher (CT-n58), and university supervisors (US-n12) completed a anonymous survey answering questions and giving comments their perceptions of the co-teaching model. Pre and post interview data was also collected to ascertain the triad's views of the student teaching experience. All data (pre and post interviews and surveys) were examined for emerging trends from each member of the group. The following items: professional development; planning time; teaching candidate and student learning; and teacher reflection emerged as positive factors of co-teaching identified by teacher candidates, cooperating teachers, and university supervisors.

\subsection{Professional Development}

$100 \%$ of participants commented on the benefits of the preservice training which emphasized collaboration and cooperation between the mentor teachers and teacher candidates. 67\% valued the co-strategies (Table 1) with one candidate stating that she "... hopes to have the opportunity to use them when she has her own classroom." The early childhood special education candidates and cooperating teachers had experience with these seven strategies prior to student teaching.

Veteran cooperating teachers and university supervisors commented that: "Due to the training, my job was so much easier. We [mentor teacher and teacher candidate] disagreed, but talked things through and real learning took place.” (CT) “As a special educator, I’ve used this and love it! I will take any student teacher who participates in co-teaching."

\subsection{Planning Time}

All participants surveyed commented on the amount of time needed and given to planning. Cooperating teachers commented that:

"The co-teaching model enhanced student learning in my classroom. Collaboration and planning with my student teacher was increased during this student teaching experience; however, this made me know that I need to spend this amount of planning time with all student teachers.”

Teacher candidates remarked that the planning time spent with their cooperating teachers and university supervisors was invaluable. Candidates were unrealistic about the time needed to properly plan to differentiate instruction and to utilize the Seven Models of Co-Teaching (Table 1).

\subsection{Teaching Candidate and Student Learning}

Again, all members of the triad commented on teacher candidate and/or student learning. Teacher candidates responded that:

"From day one, I started learning how to co-teach and do my share of the work. I have friends who did not use the co-teaching model and after my experience, they feel they did not learn as much as I did.” Another teacher candidate responded with: "I felt like I had the best student teaching experience possible. I worried about classroom management before going into student teaching, but using co-teaching, this wasn't a problem. Even when I taught the class on my own, students understood expectations; I knew the teacher was watching me. When I interview for a job, I can't wait to tell employers about my student teaching experience."

One university supervisor stated:

"I really enjoyed watching two professionals work so closely together to increase student learning and the student teacher's learning. This student teacher was confident going into the placement but came out looking like a seasoned teacher."

All teacher candidates teach a unit of study and create a pre, mid, and posttests to document student learning. 
Seven candidates discussed students who did not show academic growth. Five of the seven candidates problem-solved on their own before seeking help from their cooperating teacher or university supervisor and felt confident in their choices for reteaching strategies. The other two sought help from their cooperating teacher.

\subsection{Teacher Reflection}

Twenty-five of the twenty-nine teacher candidates commented on the benefits of their own reflections on their teaching. Two of the remaining four teacher candidates reported benefiting from their cooperating teachers' modeling of reflection or metacognition concerning success or failure of classroom strategies and instruction. All university supervisors commented on the teacher candidates' weekly reflections. One university supervisor wrote:

“In comparison to previous student teachers, this candidate's reflections were far superior. I don't know if this is because this candidate is wise beyond her years, or if the extra planning time helped. I'll be interested to see if this trend continues with candidates using the co-teaching model."

\section{Limitations}

The twenty-nine teacher candidates in this study volunteered to co-teach with their mentor teachers after meeting and getting to know their co-teachers. Additionally, the co-teachers volunteered after a conversation with their teacher candidates. Both parties were ready for the challenge and eager to learn something new. These early childhood special education teachers and candidates had practiced co-teaching in the special education setting and recognized its value prior to the training.

Prior reflective practice, collaborative courses, challenging curricula, and many prior hours of field experiences make these teacher candidates excellent; however, the student teachers in this study all attributed coteaching during student teaching as being the culminating experience needed for their future teaching success.

\section{References}

Bacharach, N., Heck, T., \& Dahlberg, K. (2010). Changing the Face of Student Teaching through Co-Teaching. Action in Teacher Education, 32, 3-14. http://dx.doi.org/10.1080/01626620.2010.10463538

Bacharach, N., Heck, T., \& Dahlberg, K. (2007). Co-Teaching in Higher Education. Journal of College Teaching and Learning, 4.

Bawens, J., \& Hourcade, J. (1995). Cooperative Teaching: Rebuilding the Schoolhouse for All Students. Austin, TX: PrEdo.

Cook, L., \& Friend, M. (1995). Co-Teaching: Guidelines for Creating Effective Practices. Focus on Exceptional Children, 26 , 3.

Friend, M., \& Cook, L. (2003). Interactions: Collaboration Skills for School Professionals (4th ed.). Boston, MA: Allyn and Bacon.

Graziano, K. J., \& Navarrete, L. A. (2012). Co-Teaching in a Teacher Education Classroom: Collaboration, Compromise, and Creativity. Issues in Teacher Education, 21, 109.

Guyton, E., \& McIntyre, D. J. (1990). Student Teaching and School Experiences. In W. R. Houston (Ed.), Handbook of Research on Teacher Education (pp. 514-534). New York, NY: Macmillan.

Hale, J. B. (2008). Response to Intervention Guidelines for Parents and Practitioners. http://www.wrightslaw.com

Keefe, E. B., Moore, V., \& Duff, F. (2004). The Four “Knows” of Collaborative Teaching. Teaching Exceptional Children, 36, 36-41.

Sandholtz, J. H. (2011). Preservice Teachers' Conceptions of Effective and Ineffective Teaching Practices. Teacher Education Quarterly, 38, 27-47.

York-Barr, J., Bacharach, N., Salk, J., Frank, J., \& Beniek, B. (2004). Team Teaching in Teacher Education: General and Special Education Faculty Experiences and Perspectives. Issues in Teacher Education, 13, 73-94. 